\title{
Environmental behavioural modification programme for street children in Alexandria, Egypt
}

G. Hosny, ${ }^{1}$ T.M. Moloukhia, ${ }^{2}$ G. Abd Elsalam ${ }^{3}$ and F. Abd Elatif ${ }^{3}$

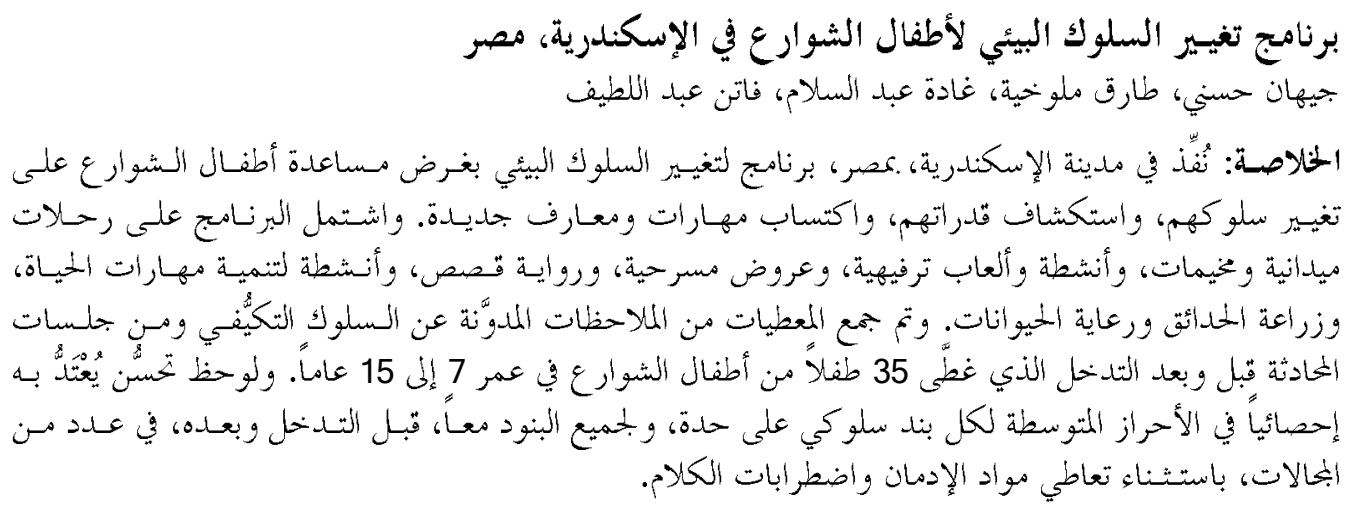

ABSTRACT An environmental behavioural modification programme was implemented in Alexandria city, Egypt, in order to help street children to change their behaviour, discover their abilities and develop and acquire new skills and knowledge. The programme included camping and field trips, recreational activities and games, role play and theatre, story-telling, life-skill activities, and gardening and animal care. Data were collected from observational sheets of adaptive behaviour and conversation sessions before and after the intervention on a sample of 35 street children aged between 7 and 15 years. The mean scores for each behavioural item and all items together before and after the intervention were significantly improved in a number of areas, except for speech disorders and substance use.

Programme de modification des comportements environnementaux des enfants des rues en Alexandrie (Égypte)

RÉSUMÉ Un programme de modification des comportements environnementaux a été mis en œuvre dans la ville d'Alexandrie (Égypte) afin d'aider les enfants des rues à modifier leur comportement, à découvrir leurs aptitudes et à développer et acquérir des compétences et des connaissances nouvelles. Ce programme comportait différents volets : camping et excursions, activités récréatives et jeux, spectacle et théâtre, narration, activités d'acquisition de compétences pour la vie, jardinage et soins aux animaux. Les données ont été collectées auprès d'un échantillon de 35 enfants des rues, âgés de 7 à 15 ans, sur la base de fiches d'observation du comportement adaptatif et de séances d'entretien avant et après l'intervention. Les scores moyens de chaque item comportemental et de l'ensemble des items avant et après l'intervention ont laissé apparaître une amélioration significative dans un certain nombre de domaines, à l'exception des troubles de la parole et de l'usage de substances psychoactives.

${ }^{1}$ Environmental Health Division, Department of Environmental Studies, Institute of Graduate Studies and Research; ${ }^{2}$ Department of Psychiatry, Faculty of Medicine; ${ }^{3}$ Faculty of Kindergarten, University of Alexandria, Alexandria, Egypt (Correspondence to G. Hosny: gihan_hosny@yahoo.com).

Received: 19/09/205; accepted: 05/12/05

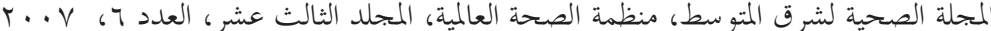




\section{Introduction}

The phenomenon of street children today has become an important subject of international concern. A street child has been defined as: "any girl or boy who has not reached adulthood (3-18 years) for whom the street has become his/her habitual abode and/or source of livelihood and who is inadequately protected, supervised or directed by responsible adults" [1]. In industrial countries, this definition may be extended to include those who spend all day in the street unsupervised [1-4]. The United Nations has estimated the population of street children worldwide at 150 million, and the number is rising daily; $40 \%$ of those are homeless and the other $60 \%$ work on the streets to support their families [5].

In Africa, the problem of street children is poorly documented [4]. Most street children are boys. The percentage of girls among street children in various developing countries ranges from only $3 \%$ to $29 \%$ [6]. Miserable living conditions and domestic violence are major reasons why these young people leave home or are sent out to the streets in order to make money to support their families. Very often women abandoned by the father of their children are left to support the house alone. As a result, family ties are broken and these children move away from their communities and form alliances with other street children in order to survive $[7,8]$. Research indicates that families with single mothers and children make up the largest group of people who are homeless in rural areas [8]. Increasingly these children are defenceless victims of violence, sexual exploitation, neglect and criminal activities $[5,8]$.

The reasons why children live on the street vary. However, there is one explanation that holds true for both developed and developing countries: poverty. Most street children go onto the street to look for a better way of living, to earn money for themselves and support their families and to find shelter $[2,3,9]$. In general, street children share common problems which may be social, physical, psychological and mental $[2,3,9]$. Social problems include poverty and illiteracy, discrimination and lack of accessible resources, a violent environment and stigmatization. Physical problems include lack of adequate nutrition, intentional and unintentional injuries, sexual and reproductive health problems and some common diseases such as skin diseases, parasitic diseases, tuberculosis and dental problems. Psychological and mental problems can be precipitated by a stressful past, transitory lifestyle, psychoactive substance use and include mental health problems such as emotional aggression, psychiatric disorders and learning difficulties $[2,3,9]$.

An earlier cross-sectional descriptive study was conducted on 100 street children attending rehabilitation institutions in order to define their problems and needs. The results of this preliminary study are reported in an earlier paper [10] and showed that street children are disproportionately victims of family breakdown, and sexual and physical abuse. They suffer from malnutrition, health problems and lack of education and they tend to display aggressive and violent behaviour. They are extremely vulnerable to communicable diseases such as tuberculosis. They are thus a potential hazard to themselves and the public at large. A behavioural modification intervention was therefore designed to address the needs, psychological issues and problems of street children in Alexandria via a programme to improve their environmental behaviour and raise their self-esteem. This paper reports an evaluation of the intervention programme.

المجلة الصحية لشرق المتو سط، منظمة الصحة العالمية، المجلد الثالث عشر، العدد ب، V... 


\section{Methods}

\section{Sample}

The original sample of 100 street children was a non-random, purposive sample, chosen from 3 central districts of Alexandria (Middle, East and West districts) that have a high concentration of street children (although all children attended the same rehabilitation institution) [10]. Children eligible for the study were those who met the definition of street child adopted by UNICEF [8].

A representative sample from the original 100 street children was chosen to take part in the environmental behavioural modification programme. A total of 42 street boys aged between 7 and 15 years were selected from the El-Horreya Institute for community development in Alexandria (an institution that only provides shelter). Boys were included in the programme if they had more than 1 behavioural problem, had not been exposed to a previous environmental behavioural modification programme, remained in the Institute during the programme, did not try to leave and had an IQ within the normal range. Most of the boys had been on the streets since before the age of 6 years. Behavioural problem include aggression and violence, stealing, begging, scavenging, commercial sex, illicit drug trafficking or substance use.

From the initial sample 7 children were excluded: 2 brothers returned to their family; 4 children had jobs outside the institute during the day and could not attend the programme activities and 1 child left the institute due to family problems. Thus, the final sample for the intervention was 35 boys: 28 aged $7-11$ years and 7 aged $12-15$ years. All gave their full consent to participate in the programme.

\section{Data collection}

Data on the children were collected using a specially designed questionnaire. The questionnaire was structured according to the handbook of the World Health Organization [2]. It assessed the family background, education status of the children and their parents, reasons for being on the street, duration of street life, presence of responsible adults, activities performed to earn money and history of police arrest. The interview was repeated twice to ensure the reliability of the data.

Each child was given the Arabic version of the Weksler IQ test for intelligence [11] and was observed using an observational sheet for adaptive behaviour, as previously described [12]. The IQ test was performed for every child in order to ensure that the chosen sample was within the normal range of IQ.

All children were medically examined at the clinic of the rehabilitation institution and interviewed in more than one setting.

An observation sheet was used in order to monitor the adaptive behaviours for each child through conversation sessions. Data were collected through conversation sessions recorded on videotape, to identify the main environmental behavioural problems. Priorities were settled and a strategic plan was developed to fulfil their needs.

The invention programme was planned and adapted from several publications concerning behaviour modification [12-19] and the researchers supervised its activities for the different age groups of children.

Pre- and postprogramme tests using the observational sheets were performed approximately $1-2$ weeks before the intervention and after application of all the programme units. 


\section{The programme}

The behavioural modification programme ran from October 2001 to April 2003. The programme was designed in 7 main units: outdoors and recreational education; urban and health education; heritage and museum education; moral and religious education; human rights and peace education; economic and civic education; and future and sustainable education. The programme was applied through several activities, including: camping and field trips, recreational activities and games, role play and theatre, positive actions and experiences, storytelling, life-skill activities and gardening and animal care.

The 1st unit of the programme concerned with outdoors and recreational education was conducted through trips and camping. The unit aimed to provide opportunities to encourage enjoyment, appreciation and awareness of the environment so as to help change attitudes by exposing children to new and relevant experiences that would lead to better understanding of themselves as well as their environment $[13,14,16]$.

The 2nd unit included urban and health education. The urban education part aimed to create understanding of the social, physical and natural characteristics of the urban environment and their interrelationships so as to help children deal with their urban environment $[15,17,18]$. The health education unit was designed to give the boys basic information about the changes that take place in their bodies during the different ages, teaching them skills to help them adopt positive attitudes for sustaining healthy lifestyles and avoiding risk behaviours. The major items covered by the health education were nutrition and dietary practices, personal health, correct lifestyles for health promotion and disease prevention, and first-aid skills in order to help them survive street life, as they face problems such as accidents, sexual abuse, violence and substance use [20,21].

The 3rd unit of heritage and museum education aimed to help children acquire new skills related to national history; increase their awareness of their environment; develop feelings of respecting and belonging to society and its culture, values, thoughts and traditions; help them to change their attitudes towards historic places; and understand how the past can affect the present positively. The activities of heritage and museum education can also help children to find jobs such as selling small things they have made or plan small income-generating projects [20].

The 4th and the 5th units were concerned with moral and religious education, and human rights and peace education, respectively, and were considered complementary to other programme units. Religious and moral values were encouraged through certain activities such as religious stories, prayer and guidance conversations to help the children to have real internal change, understand their rights and be peace seekers. Street children all over the world have common problems, one of which is aggression $[1,4]$, so they need peace and human rights education which can help them to respect themselves, others and others' possessions.

The 6th unit of economic and civic education was concerned with understanding the developmental processes within and between countries and rich and poor people, in order to give the children an understanding of the economic and political system. It was designed to be learned through activities to help children know their rights and duties, acquire new skills to find jobs and to make plans for their future.

Finally, the 7th unit of future and sustainable education was designed to help the children learn suitable ways to develop their

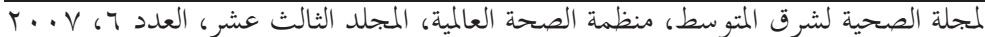


skills and personality in order to find jobs and plan for their future.

\section{Data analysis}

The data were analysed by SPSS, version 10. They were checked for accuracy and normality using the Kolmogorov-Smirnov and Shapiro-Wilk tests. The data were found to be not normally distributed and were presented as means and standard deviations (SD). The Wilcoxon signed rank test was used as a non-parametric test for comparison between the results before and after the intervention (paired comparison of the 13 items). Percentage change was calculated for each item and for total scores of the programme before and after the intervention. The Mann-Whitney test was used for comparison between the 2 subgroups while the Kruskal-Wallis test was used for comparison between more than 2 subgroups. Spearman rank correlation coefficient was calculated to measure the mutual correspondence between 2 variables. $P \leq 0.05$ was the level of significance.

\section{Results}

In the current study a behavioural modification intervention was designed for a sample of 35 street children in order to raise their self-esteem and ameliorate their behaviour. The characteristics of the sample of street children selected for the intervention are presented in Tables 1 and 2. In the present study the observation sheet that was designed to characterize the children preintervention showed the main behavioural factors were: antisocial behaviour (46\%), aggressive behaviour (43\%), substance use $(43 \%)$, helper (one who offers help to others and tries to provide help to others if required) $(42 \%)$, destructive behaviour $(37 \%)$ and paranoia (31\%). Street activities performed to earn money were:
Table 1 Descriptive data of the selected sample of street children before the intervention $(n=35)$

\begin{tabular}{|c|c|}
\hline Variable & $\%$ \\
\hline \multicolumn{2}{|l|}{ Family background } \\
\hline Parents still married & 14 \\
\hline Parents divorced or separated & 52 \\
\hline Death of 1 or both parents & 11 \\
\hline Step-parents & 23 \\
\hline \multicolumn{2}{|l|}{ Child's relation with his family } \\
\hline Good & 9 \\
\hline Moderate & 34 \\
\hline Bad & 46 \\
\hline None & 11 \\
\hline \multicolumn{2}{|l|}{ Age of going on the streets (years) } \\
\hline$<6$ & 83 \\
\hline $6-9$ & 17 \\
\hline$>10$ & 0 \\
\hline \multicolumn{2}{|l|}{ Reasons for going on the streets } \\
\hline Earn money & 12 \\
\hline Escape family conflicts & 57 \\
\hline Find shelter & 11 \\
\hline Escape physical abuse at home & 11 \\
\hline Escape from children's institution & 3 \\
\hline Live the way he wants to live & 6 \\
\hline \multicolumn{2}{|l|}{ Educational status of the child } \\
\hline Student & 3 \\
\hline Can read and/or write & 62 \\
\hline Illiterate & 35 \\
\hline \multicolumn{2}{|l|}{ Place of sleeping at night } \\
\hline In the street & 92 \\
\hline At home & 8 \\
\hline \multicolumn{2}{|l|}{ Street activities } \\
\hline Selling small items & 40 \\
\hline Washing cars & 31 \\
\hline Scavenging & 9 \\
\hline Stealing & 6 \\
\hline Begging & 9 \\
\hline Survival sex & 3 \\
\hline Drug trafficking & 3 \\
\hline \multicolumn{2}{|l|}{ Favourite activity } \\
\hline Fishing & 100 \\
\hline Cycling & 46 \\
\hline Games & 46 \\
\hline Dancing & 37 \\
\hline
\end{tabular}




\begin{tabular}{lr}
\hline Eastern Mediterranean Health Journal, Vol. 13, No. 6 \\
\hline \multicolumn{2}{l}{ Table 1 Descriptive data of the selected } \\
sample of street children before the \\
intervention $(\boldsymbol{n}=\mathbf{3 5}$ ) (concluded) \\
\hline Variable & $\%$ \\
\hline Arts & 29 \\
Gardening & 29 \\
Handicrafts & 23 \\
Singing & 20 \\
Reading & 3 \\
Type of peer relations & \\
Few & 37 \\
Many & 29 \\
Few and superficial & 11 \\
Many and deep & 8 \\
Many and for a purpose & 6 \\
Few and deep & 3 \\
Few and for a purpose & 3 \\
Few, superficial and for a purpose & 3
\end{tabular}

selling small items (40\%), washing cars $(31 \%)$, begging $(9 \%)$, scavenging $(9 \%)$, stealing $(6 \%)$ and drug trafficking $(3 \%) ; 3 \%$ engaged in survival sex (i.e. sex for rewards but not money) but none reported being involved in commercial sex. Favourite activities were fishing $(100 \%)$, cycling $(46 \%)$, games (46\%) and dancing (37\%).

From the results of the preliminary study the intervention programme was designed to target and modify the behaviour problems identified. Table 3 shows the results of each behavioural item and the items combined, before and after the intervention. The Ztest values, the percentage change values and the correlation coefficients showed improvements in the targeted behaviours and suggest that the programme had been successful.

The percentage change of total scores on behavioural items before and after the intervention were used to compare children who had a behavioural disorder and those who did not (Table 4). The only behaviours disorders that showed a significant differ-
Table 2 Behavioural profile of the selected sample of street children before the intervention $(n=35)$

\begin{tabular}{|c|c|}
\hline Variable & $\%$ \\
\hline \multicolumn{2}{|l|}{ Child abuse suffered } \\
\hline Verbal & 94 \\
\hline Physical & 94 \\
\hline Sexual & 89 \\
\hline Emotional & 8 \\
\hline \multicolumn{2}{|l|}{ Smoking and substance use } \\
\hline Smoking & 100 \\
\hline Always use substances & 43 \\
\hline Sometimes use substances & 57 \\
\hline Never use substances & 0 \\
\hline \multicolumn{2}{|l|}{ Behavioural issues } \\
\hline Antisocial behaviour & 46 \\
\hline Aggressive behaviour & 43 \\
\hline Helper & 42 \\
\hline Destructive behaviour & 37 \\
\hline Paranoia & 31 \\
\hline Homosexuality & 26 \\
\hline Jealousy & 26 \\
\hline Narcissism & 25 \\
\hline Nail biting & 20 \\
\hline Avoidance & 17 \\
\hline Lying & 17 \\
\hline Nocturnal enuresis & 17 \\
\hline Schizoid behaviour & 17 \\
\hline Dependence & 14 \\
\hline Nutrition disorders & 11 \\
\hline Speech disorders & 11 \\
\hline Phobia & 8 \\
\hline Stealing & 6 \\
\hline Temper tantrums & 6 \\
\hline Sleep disorders & 3 \\
\hline Depressive disorders & 3 \\
\hline
\end{tabular}

ence were helper personality, narcissistic personality and passive aggressive personality $(P \leq 0.05$, between children displaying the behaviour and those not). No other behaviours were significant. Other items of behaviour that showed a significant decrease were speech disorders, homosexuality and substance use $(P \leq 0.05)$, suggesting an effect of the programme. 
1444

\begin{tabular}{|c|c|c|c|c|c|c|c|c|c|}
\hline \multirow[t]{2}{*}{ Behaviour item } & \multicolumn{2}{|c|}{ Before } & \multicolumn{2}{|c|}{ After } & \multicolumn{2}{|c|}{ Z-test $^{\mathrm{a}}$} & \multicolumn{2}{|c|}{ Correlation } & \multirow{2}{*}{$\begin{array}{c}\% \\
\text { change }\end{array}$} \\
\hline & Range & $\begin{array}{c}\text { Mean } \\
\text { score } \\
\text { (SD) }\end{array}$ & Range & $\begin{array}{c}\text { Mean } \\
\text { score } \\
\text { (SD) }\end{array}$ & Z-value & $P$-value & $r$-value & $P$-value & \\
\hline Independent behaviour & $16-36$ & $\begin{array}{c}7.89 \\
(3.20)\end{array}$ & $3-14$ & $\begin{array}{l}28.97 \\
(6.44)\end{array}$ & 5.163 & $<0.001$ & 0.0285 & 0.096 & 267 \\
\hline Economic activities & $6-15$ & $\begin{array}{c}5.57 \\
(1.24)\end{array}$ & $3-8$ & $\begin{array}{l}11.46 \\
(1.85)\end{array}$ & 5.190 & $<0.001$ & 0.457 & 0.001 & 106 \\
\hline Vocational activities & $6-14$ & $\begin{array}{c}3.89 \\
(1.57)\end{array}$ & $1-6$ & $\begin{array}{c}9.23 \\
(2.33)\end{array}$ & 5.174 & $<0.001$ & 0.475 & 0.004 & 137 \\
\hline Responsible behaviour & $7-18$ & $\begin{array}{c}4.26 \\
(1.88)\end{array}$ & $1-8$ & $\begin{array}{l}12.23 \\
(3.68)\end{array}$ & 5.169 & $<0.001$ & 0.526 & 0.001 & 187 \\
\hline Social relations & $10-20$ & $\begin{array}{c}5.23 \\
(1.26)\end{array}$ & $3-7$ & $\begin{array}{l}15.09 \\
(2.08)\end{array}$ & 5.175 & $<0.001$ & 0.205 & 0.237 & 189 \\
\hline Destructive behaviour & $8-19$ & $\begin{array}{c}4.77 \\
(1.29)\end{array}$ & $3-8$ & $\begin{array}{l}16.94 \\
(2.41)\end{array}$ & 5.151 & $<0.001$ & -0.099 & 0.571 & 255 \\
\hline Antisocial behaviour & $3-6$ & $\begin{array}{c}1.14 \\
(0.85)\end{array}$ & $0-3$ & $\begin{array}{c}5.23 \\
(0.97)\end{array}$ & 5.218 & $<0.001$ & 0.102 & 0.559 & 359 \\
\hline Rebellious behaviour & $6-11$ & $\begin{array}{c}2.77 \\
(1.09)\end{array}$ & $0-5$ & $\begin{array}{c}9.91 \\
(1.15)\end{array}$ & 5.188 & $<0.001$ & -0.063 & 0.718 & 258 \\
\hline Non-trustable behaviour & Ir $3-6$ & $\begin{array}{l}1.45 \\
(0.85)\end{array}$ & $0-3$ & $\begin{array}{c}5.23 \\
(1.06)\end{array}$ & 5.201 & $<0.001$ & -0.138 & 0.430 & 261 \\
\hline Withdrawal behaviour & $5-10$ & $\begin{array}{c}2.11 \\
(0.99)\end{array}$ & $0-4$ & $\begin{array}{c}8.29 \\
(0.96)\end{array}$ & 5.191 & $<0.001$ & -0.283 & 0.100 & 293 \\
\hline Non-acceptable habits & $10-22$ & $\begin{array}{c}5.26 \\
(1.17)\end{array}$ & $3-8$ & $\begin{array}{l}19.31 \\
(2.82)\end{array}$ & 5.169 & $<0.001$ & 0.007 & 0.966 & 267 \\
\hline $\begin{array}{l}\text { Psychological and } \\
\text { emotional disorders }\end{array}$ & $20-26$ & $\begin{array}{c}7.63 \\
(1.54)\end{array}$ & $5-11$ & $\begin{array}{l}24.09 \\
(1.74)\end{array}$ & 5.174 & $<0.001$ & -0.131 & 0.453 & 216 \\
\hline $\begin{array}{l}\text { Complementary } \\
\text { information }^{\mathrm{b}}\end{array}$ & $5-10$ & $\begin{array}{c}2.40 \\
(1.12)\end{array}$ & $0-4$ & $\begin{array}{c}8.60 \\
(1.35)\end{array}$ & 5.183 & $<0.001$ & 0.051 & 0.773 & 258 \\
\hline Total & $152-195$ & $\begin{array}{l}54.31 \\
(7.99)\end{array}$ & $41-73$ & $\begin{array}{l}174.57 \\
(12.42)\end{array}$ & 5.161 & $<0.001$ & 0.337 & 0.047 & 221 \\
\hline
\end{tabular}

a-values were statistically significant for the scores given for behavioural items before and after intervention at $\mathrm{P}<$ 0.001 .

${ }^{b}$ Moral and religious information; health information; human rights; environmental education; economic information, etc.

$S D=$ standard deviation

\section{Discussion}

Street children constitute a considerable part of the homeless population, who are highly disadvantaged and forgotten. They represent a hazardous environmental problem in all societies due to the behaviours they acquire from street life and the psycho- 


\begin{tabular}{|c|c|c|c|c|c|c|}
\hline \multirow[t]{2}{*}{ Behaviour item } & \multicolumn{2}{|c|}{$\begin{array}{l}\text { Does not } \\
\text { have the } \\
\text { behaviour }\end{array}$} & \multicolumn{2}{|c|}{$\begin{array}{c}\text { Has the } \\
\text { behaviour }\end{array}$} & \multicolumn{2}{|c|}{ Z-test } \\
\hline & $n$ & Mean (SD) & $n$ & Mean (SD) & Z-value & $P$-value \\
\hline Dependent & 32 & $225(43)$ & 3 & $246(23)$ & -0.825 & 0.446 \\
\hline Schizoid & 29 & $223(43)$ & 6 & $243(29)$ & -1.051 & 0.312 \\
\hline Helper & 21 & $206(48)$ & 14 & $241(31)$ & -2.627 & $0.008^{*}$ \\
\hline Avoidant & 29 & $224(42)$ & 6 & $239(39)$ & -0.919 & 0.379 \\
\hline Loving & 29 & $224(44)$ & 6 & $238(29)$ & -0.657 & 0.535 \\
\hline Enthusiastic & 14 & $242(34)$ & 21 & $217(44)$ & -1.919 & 0.056 \\
\hline Peacemaker & 34 & $227(42)$ & 1 & $209(15)$ & -0.475 & 0.743 \\
\hline Paranoid & 23 & $237(36)$ & 12 & $206(47)$ & -1.894 & 0.057 \\
\hline Phobic & 32 & $289(43)$ & 3 & $202(11)$ & -1.473 & 0.157 \\
\hline Passive aggressive & 22 & $242(31)$ & 13 & $200(45)$ & -2.936 & $0.003^{*}$ \\
\hline Narcissistic & 26 & $237(36)$ & 6 & $196(43)$ & -2.435 & $0.013^{*}$ \\
\hline Sleep disorders & 34 & $227(42)$ & 1 & $231(44)$ & -0.099 & 0.971 \\
\hline Nocturnal enuresis & 29 & $229(29)$ & 6 & $213(55)$ & -0.863 & 0.356 \\
\hline Jealous & 26 & $229(28)$ & 9 & $220(53)$ & -0.491 & 0.643 \\
\hline Nutrition disorders & 30 & $229(44)$ & 5 & $214(21)$ & -1.108 & 0.277 \\
\hline Destructive & 21 & $236(32)$ & 14 & $212(51)$ & -1.751 & 0.083 \\
\hline Aggressive & 22 & $237(31)$ & 13 & $210(52)$ & -1.844 & 0.067 \\
\hline Temper tantrums & 33 & $231(38)$ & 2 & $160(68)$ & -1.706 & 0.101 \\
\hline Lying & 29 & $230(42)$ & 6 & $209(37)$ & -1.247 & 0.218 \\
\hline Stealing & 24 & $236(31)$ & 11 & $207(55)$ & -1.670 & 0.099 \\
\hline Substance use & 20 & $243(33)$ & 15 & $205(43)$ & -2.834 & $0.004^{*}$ \\
\hline Speech disorders & 31 & $231(43)$ & 4 & $196(91)$ & -2.022 & $0.043^{*}$ \\
\hline Homosexuality & 27 & $237(39)$ & 8 & $193(36)$ & -2.730 & $0.005^{*}$ \\
\hline
\end{tabular}

logical problems that leave them vulnerable. Sometimes orphaned children have taken the decision to run away from residential homes. A high proportion of street children have been forcibly thrown out of the family home by uncaring or poverty-stricken family members. The reasons are mostly conflicts with parents or step-parents, broken homes or ill treatment by family members. Some are rural children who have simply become attracted to city life, perhaps through the mass media $[2,3,9,10,22]$. In our study group $12 \%$ of the children went out to the streets to earn money, $57 \%$ to escape family problems and $11 \%$ to escape physical abuse at home.

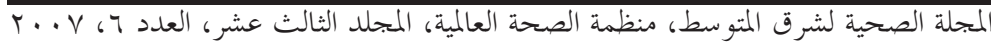


The present study was designed to define the psychological profile of a sample of 35 street children before and after participation in a behavioural modification intervention in order to establish how effective the programme was in raising their self-esteem and ameliorating their behaviour. The programme was based on training the children to behave in a more appropriate and socially acceptable manner [20]. The programme included different units, which contained variable activities that were chosen carefully to be appropriate with the nature and ages of the studied sample. The intervention was applied to help children to change their behaviour, fulfil their needs through activities, discover their abilities and develop and acquire new skills. The results of the intervention showed a significant improvement in some aspects of the children's behaviour after attending the programme compared to before, using statistical analysis of scores for each behavioural item. The programme activities seemed to be successful in modifying the street children's behaviour.

In Egypt, there are currently a number of projects sponsored by the President of the country and other governmental and nongovernmental organizations (NGOs) to support street children through the declaration of the second decade for the protection and welfare of the Egyptian child (2000-10). This declaration has signified that childhood issues should occupy a place at the centre of future plans for the community and will focus on guaranteeing health and education in cultural and social areas, backed up by strict legislation to protect mothers and children and to guarantee their safety and stability [23]. The National Council of Childhood and Motherhood (NCCM) uses the term "homeless child" instead of "street child", which reflects similar concepts, and defines them as children who lack any kind of care and protection, and are vulnerable to physical and psychological danger, and exploitation of their basic rights [24]. The NCCM introduce in March 2003 a national strategy to define, characterize, protect, integrate and rehabilitate street children in Egypt [25]. The NCCM introduced a protection and caring project for street children involved with drugs in collaboration with NGOs and police stations in Cairo, Giza and Alexandria [26]. The project aims to support the health, nutritional, social and cultural care services for street children through reception centres for arrested children to ensure care and safety for them. The NCCM arranged a workshop to discuss and verify the working guidelines for the dealers with street children (part of the project was funded by the NCCM, the United Nations Office on Drugs and Crime and the Danish Embassy in Cairo) in order to raise the performance of those who deal with street children (psychiatrists, sociologists, police officers, caring institutes, NGO staff, etc.) to protect and prevent street children from smoking and substance abuse [27].

Egyptian NGOs such as the Hope Village Society in Cairo and El-Horriya Institute in Alexandria provide some services for street children. The Hope Village Society in Egypt is the best model of NGOs that deal with street children. It is a private voluntary association established by a group of businessmen and women and is dedicated to providing attention, care, education and training to children in difficult circumstances, with an emphasis on street children. The Society has successfully expanded from caring for a few boys in one shelter to a number of separate sites around Cairo using a mobile unit, reception day care centres and short-term and long-term shelters [28]. The Society provides care and shelter and rehabilitation and training and facilitates government education for street children, runs training projects to sustain continuity 
and stability of society, carries out scientific research on the phenomenon of street children, provides small loans to families of street children and re-integrates them with the community. It also provides subdonations and technical help and training to other NGOs that work in the same field and it networks and exchanges experiences with other associations and organizations [28]. The Society targets training the children through several vocational programme workshops on handicrafts, and electrical, carpentry or plumbing products. It offers religious, cultural and recreational programmes through monthly trips, fun parties and summer camping. A new programme called the Center for Habilitating and Integrating Young Street Mothers, introduces special care for young mothers who are victims of sexual and physical abuse [28].

The current programme for environmental behavioural modification of street children is the first programme to be applied in Egypt and needs to be further applied in different institutions and localities. Also, further studies are required for long-term behavioural modification programme to fulfil the needs of street children. Knowing the risk factors, efforts on a wider scale should be addressed at an earlier level of intervention to the target population to prevent the phenomenon of street children.

\section{References}

1. InterNGO programme on street children and street youth. Summary of proceedings. Subregional seminar for the Mediterranean, Marseilles, October 24-27, 1983.

2. World Health Organization programme on substance abuse. Geneva, World Health Organization, 1995.

3. Working with street children: a training package on substance use, sexual reproductive health including HIVIAIDS. Geneva, World Health Organization, 2000.

4. United Nations Children's Fund. The state of the world's children 1999. Oxford, Oxford University Press, 1998.

5. Vissing YM. Out of sight, out of mind: homeless children and families in smalltown America. Lexington, Kentucky, University Press of Kentucky, 1996.

6. Shelby B. Desperate and on the street. World press review, 1992, 39:26.

7. Who cares? A special report on street children. Urban age, Spring, 2000.
8. El-Baz SH. Children in difficult circumstances: institutions and inmates. Cairo, United Nations Children's Fund, 1996.

9. Substance use and health training for street educators. Geneva, World Health Organization, 1999.

10. Salem EM, Abd El-Latif F. Sociodemographic characteristics of street children in Alexandria. Eastern Mediterranean health journal, 2002, 8(1):64-73.

11. Esmail ME, Melika LK ( translators). [Weksler scale for children intelligence, 6th ed.] Cairo, Dar El-Nahda Elarabia, 1993 [Arabic edition].

12. Sadek F. [Scale for adaptive behaviour, 2nd ed.] Cairo, Ain Shams University Press, 1985 [in Arabic].

13. Melika LK. Behavior modification. ElKuwait, Dar Elkalm, 1990 [in Arabic].

14. United States Department of Agriculture (USDA) Report. Washington DC, Natural Resources Conservation Service, Social Sciences Institute, 2002. 
15. Wertheim E. Learning and behavioral modification. A technical note. Boston, Massachusetts, Northeastern University, 2004 [online article] (http://web.cba. neu.edu/ ewertheim/indiv/learn.htm, accessed 24 April 2007).

16. Easler DD, Pease JL. Evaluating the effectiveness of residential environmental education programs in fostering positive attitudes toward wildlife. Journal of environmental education, 1999, 3(1):33-9.

17. Palmer JA. Environmental education in the 21st century: theory, practice, progress and promise. New York, Routledge, 1998.

18. Neal PH, Palmer JA. The handbook of environmental education. New York, Routledge, 1994.

19. Kaplan HI, Sadock BJ, Grebb JA. Synopsis of psychiatry, behavioral sciences, clinical psychology, 7th ed [Middle East edition]. Baltimore, Williams \& Wilkins, 1994:503-12

20. Monteiro MG, ed. Young people and substance use: a manual to create, use and evaluate educational materials and activities. Special report. Geneva, World Health Organization, 1999.

21. Working with street children. A training package on substance use, sexual reproductive health including HIVIAIDS and STDs. Geneva, World Health Organization, 2000 (WHO/MSD/MDP/00.14).

22. Substance use among street children and other children and youths in especially difficult circumstances. Geneva, World Health Organization, 1997 (WHO Fact Sheet, No. 151).

23. Declaration for the Second Decade for the Protection and Welfare of the Egyptian Child (2000-2010). Cairo, National Council for Childhood and Motherhood, February, 2000.

24. A civil society forum for North Africa and The Middle East on promoting and protecting the rights of street children, 3-6 March 2004, Cairo, Egypt. London, Consortium for Street Children, 2004 (http://www. streetchildren.org.uk/reports/northafrica. pdf, accessed 30 October 2007).

25. Conference for announcing the national strategy to protect, integrate and rehabilitate street children in Egypt, March 2003. Cairo, National Council of Childhood and Motherhood, 2003.

26. A project for protection and caring of street children from drugs in collaboration with NGOs and police stations, April 2004. Cairo, National Council of Childhood and Motherhood, 2004.

27. Workshop for testing the training working guidelines for the dealers with street children, April 2004. Cairo, National Council of Childhood and Motherhood, 2004.

28. Hope Village Society [website] (http:// www.egyhopevillage.com/indexeng.htm, accessed 23 April 2007). 